\title{
TRIPODAL LIGANDS WITH MIXED DONORS. SYNTHESIS OF 2-DIPHENYLPHOSPHINOMETHYL-2- PHENYLTHIOMETHYL-1-METHOXYPROPANE (PSO) AND ITS TRANSITION METAL COMPLEXES
}

\author{
SHIUH-TZUNG LIU,* CHONG-LUNG TSAO, MING-CHU CHENG and \\ SHIE-MING PENG \\ Department of Chemistry, National Taiwan University, Taipei, Taiwan 10764, R.O.C.
}

(Received 20 March 1990; accepted 7 June 1990)

\begin{abstract}
A tripodal ligand containing phosphorus, sulphur and oxygen donors has been synthesized and its coordination in chromium( $(0)$, molybdenum $(0)$, tungsten $(0)$, manganese(I) and palladium(II) complexes has been investigated. X-ray crystal structures of the chromium, tungsten and palladium compounds have been determined, and the conformations of the six-membered chelate rings of these complexes are discussed.
\end{abstract}

The design of new polydentate ligands for coordination studies has been interesting and challenging work. As part of our interest in tripodal terdentate ligands, we wished to synthesize such species which contain both "soft" and "hard" donor sites. Such ligands could be used to study the selectivity studies toward transition metals. In our early work, ${ }^{1}$ we described several tripodal ligands that contain only two different donor sites, 1 and 2. However, tripodal terdentates containing three different donor atoms would be more attractive for coordination chemists. Only a few such species have been reported, ${ }^{2,3}$ and none containing phosphorus. Here, we report the synthesis of a tripodal phosphine ligand with three different donors, 2-diphenylphosphinomethyl-2phenylthiomethyl-1-methoxypropane (abbreviated as PSO) 3, and its complexation toward various transition metals.

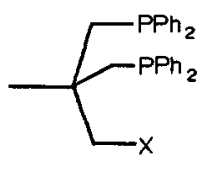

I $X=O M e\left(\mathrm{P}_{2} \mathrm{O}\right)$

$2 x=\operatorname{SPh}\left(P_{2} S\right)$

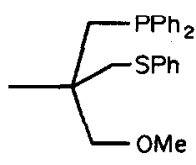

3

\footnotetext{
* Author to whom correspondence should be addressed.
}

\section{RESULTS AND DISCUSSION}

\section{Synthesis of ligand}

The synthetic approach to 3 is shown in Scheme 1. From 4 , compound 5 was prepared according to a modification of the reported method. ${ }^{4}$ The oxetane ring was opened by the benzenethiolate anion to generate the sulphide-alcohol 6. Mesylation of the hydroxy function of 6, followed by treatment with diphenylphosphide anion, produced the desired phosphine compound ( \pm$)-3$, after anaerobic chromatography of the crude product on a column of degassed silica gel. This terdentate was characterized by a spectroscopic method and elemental analysis. The ${ }^{31} \mathrm{P}$ NMR spectrum shows a single peak at $-24.78 \mathrm{ppm}$, upfield from the reference of $85 \% \mathrm{H}_{3} \mathrm{PO}_{4}$, which is the characteristic absorption of a tertiary phosphine.

\section{Group VI complexes}

The group VI carbonyl complexes, (PSO)M $(\mathrm{CO})_{4}$, in which $\mathrm{M}=\mathrm{Cr}$ (8a), Mo (8b) and W $(\mathbf{8 c})$, were readily prepared by means of the direct ligand substitution reaction. The complexes $8 \mathbf{a}-\mathbf{8 c}$ were made by the thermal reaction of 3 with the corresponding $\mathrm{M}(\mathrm{CO})_{6}$ in boiling, degassed xylene. Attempts to prepare (PSO)Mo(CO) ${ }_{3}$ failed. The substitution reaction of $\mathrm{Mo}\left(\eta^{6}\right.$-cyclohepatriene) $(\mathrm{CO})_{3}$ by PSO led to the isolation of $8 \mathrm{~b}$ instead 


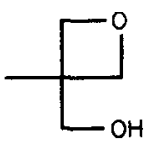

4
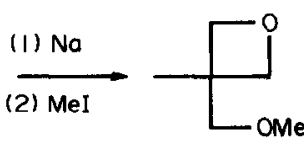

5

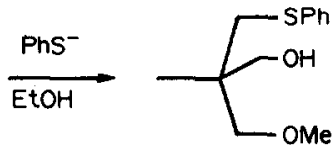

6

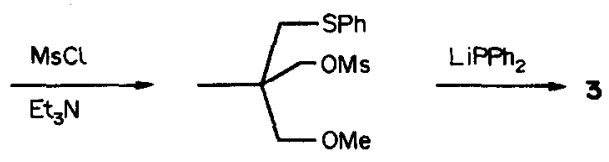

7

Scheme 1 .

of $(\mathrm{PSO}) \mathrm{Mo}(\mathrm{CO})_{3}$. Other thermal substitution reactions or photochemical activation of $\mathbf{8 b}$ were unable to force the oxygen donor to become coordinated. All purified tetracarbonyl metal complexes have been identified by both spectroscopic and elemental analyses; their data are summarized in Table 1.

Crystals of $8 \mathbf{a}$ and $8 \mathbf{c}$ were grown from hexane and dichloromethane solvents and are isomorphous. The structure of $\mathbf{8 a}$ shows the chromium centre to have an octahedral stereochemistry with four carbonyls, and the phosphorus and the sulphur donors of PSO bound to the metal (Figs 1 and
2). All bond distances and bond angles are within normal ranges; some selected bond distances and bond angles are given in Table 2 . The $\mathbf{M}-\mathrm{C}$ distances for both 8a and $8 \mathrm{c}$ trans to phosphorus are longer than those trans to sulphur; this effect is believed to be a consequence of the presence of metal-to-sulphur $\pi$-back-donation. ${ }^{2,4}$

\section{Manganese(I) complexes}

From the reaction of equimolar 3 and $\mathrm{Mn}(\mathrm{CO})_{5}$ $\mathrm{Br}$ in boiling chloroform, a yellow crystalline solid of complex 9 was isolated. The IR spectrum

Table 1. Spectroscopic and analytical data of complexes 8a-8c

\begin{tabular}{|c|c|c|c|c|}
\hline Complex & ${ }^{1} \mathrm{H}$ NMR & $\begin{array}{c}{ }^{31} \mathrm{P} \text { NMR } \\
\left(\Delta_{\delta \mathrm{P}}\right)^{a}\end{array}$ & $\begin{array}{l}\operatorname{IR}[v(C O)] \\
\left(\mathrm{cm}^{-1}\right)\end{array}$ & Analysis \\
\hline $8 \mathbf{a}$ & $\begin{array}{l}7.56-7.34(\mathrm{~m}, 15 \mathrm{H}), 3.05(\mathrm{~s}, 3 \mathrm{H}) \\
2.82-3.09(\mathrm{~m}, 4 \mathrm{H}) \\
2.63\left(\mathrm{dd}, J=24.6, J_{\mathrm{P}-\mathrm{c}-\mathrm{H}}=8 \mathrm{~Hz}, 1 \mathrm{H}\right) \\
2.35\left(\mathrm{dd}, J=24.6, J_{\mathrm{P}-\mathrm{C}-\mathrm{H}}=8 \mathrm{~Hz}, 1 \mathrm{H}\right) \\
0.86(\mathrm{~s}, 3 \mathrm{H})\end{array}$ & $37.36(62.1)$ & $\begin{array}{l}2008 \\
1960 \\
1912 \\
1885\end{array}$ & $\begin{array}{r}\mathrm{C}_{28} \mathrm{H}_{27} \mathrm{OPSC} \mathrm{r} \\
\text { Calc. } \mathrm{C}, 60.2 ; \mathrm{H}, 4.9 \\
\text { Found } \mathrm{C}, 60.1 ; \mathrm{H}, 5.1\end{array}$ \\
\hline $8 \mathbf{b}$ & $\begin{array}{l}7.62-7.35(\mathrm{~m}, 15 \mathrm{H}), 3.12(\mathrm{~s}, 3 \mathrm{H}) \\
3.18(\mathrm{~d}, J=10.8 \mathrm{~Hz}, 1 \mathrm{H}) \\
3.02(\mathrm{~d}, J=10.8 \mathrm{~Hz}, 1 \mathrm{H}) \\
3.02(\mathrm{~d}, J=9.4 \mathrm{~Hz}, 1 \mathrm{H}) \\
2.94(\mathrm{~d}, J=9.4 \mathrm{~Hz}, 1 \mathrm{H}) \\
2.67\left(\mathrm{dd}, J=15, J_{\mathrm{p}-\mathrm{C}-\mathrm{H}}=7 \mathrm{~Hz}, 1 \mathrm{H}\right) \\
2.47\left(\mathrm{dd}, J=15, J_{\mathrm{p}-\mathrm{C}-\mathrm{H}}=7 \mathrm{~Hz}, 1 \mathrm{H}\right) \\
0.95(\mathrm{~s}, 3 \mathrm{H})\end{array}$ & $18.51(43.3)$ & $\begin{array}{l}2019 \\
1976 \\
1916 \\
1891\end{array}$ & $\begin{array}{r}\mathrm{C}_{28} \mathrm{H}_{27} \mathrm{OPSMo} \\
\text { Calc. C, 55.8; } \mathrm{H}, 4.5 \\
\text { Found } \mathrm{C}, 56.2 ; \mathrm{H}, 4.5\end{array}$ \\
\hline $8 c$ & $\begin{array}{l}7.70-7.32(\mathrm{~m}, 15 \mathrm{H}), 3.13(\mathrm{~s}, 3 \mathrm{H}) \\
3.30(\mathrm{~d}, J=11.4 \mathrm{~Hz}, 1 \mathrm{H}) \\
3.16(\mathrm{~d}, J=11.4 \mathrm{~Hz}, 1 \mathrm{H}) \\
3.01(\mathrm{~d}, J=5.8 \mathrm{~Hz}, 1 \mathrm{H}) \\
2.94(\mathrm{~d}, J=5.8 \mathrm{~Hz}, 1 \mathrm{H}) \\
2.80\left(\mathrm{dd}, J=14.6, J_{\mathrm{P}-\mathrm{C}-\mathrm{H}}=8 \mathrm{~Hz}, 1 \mathrm{H}\right) \\
2.60\left(\mathrm{dd}, J=14.6, J_{\mathrm{P}-\mathrm{C}-\mathrm{H}}=8 \mathrm{~Hz}, 1 \mathrm{H}\right) \\
0.97(\mathrm{~s}, 3 \mathrm{H})\end{array}$ & $3.36(28.1)$ & $\begin{array}{l}2014 \\
1929 \\
1910 \\
1883\end{array}$ & $\begin{array}{r}\mathrm{C}_{28} \mathrm{H}_{27} \mathrm{OPSW} \\
\text { Calc. } \mathrm{C}, 48.7 ; \mathrm{H}, 3.9 \\
\text { Found } \mathrm{C}, 49.5 ; \mathrm{H}, 4.0\end{array}$ \\
\hline
\end{tabular}

${ }^{a}$ Coordination chemical shifts $\left(\Delta_{\delta \mathrm{P}}\right)=\delta_{\mathrm{p}}($ complex $)-\delta_{\mathrm{p}}($ free ligand $)$, in ppm. 


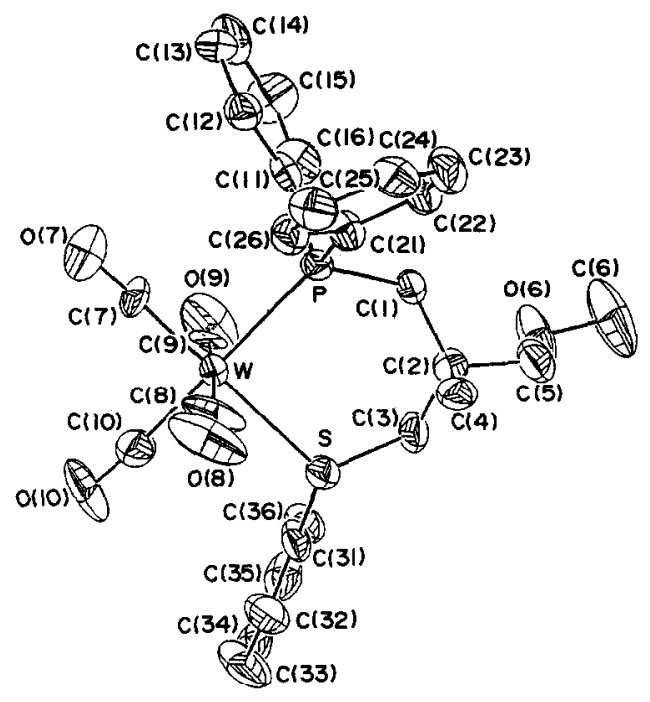

Fig. 1. The ORTEP drawing of $8 \mathrm{c}$.

$\left(v(C O)=2034,1961,1907 \mathrm{~cm}^{-1}\right)$ of 9 shows three terminal $\mathrm{CO}$ stretches in fac-geometry. ${ }^{5}$ Both ${ }^{31} \mathrm{P}$ and ${ }^{1} \mathrm{H}$ NMR spectra indicate that phosphorus and sulphur donors bind to the metal centre with the oxygen site uncoordinated. This evidence indicates the structure of 9 to be an octahedral complex with phosphorus, sulphur and bromide in a facarrangement.

Another way to achieve complex 9 is by the reaction of 3 and $\mathrm{Mn}_{2}(\mathrm{CO})_{10}$ to generate [(PSO)Mn $\left.(\mathrm{CO})_{3}\right]_{2}(\mathbf{1 0})$, followed by treatment with bromine (Scheme 2). It is interesting to note that both IR and ${ }^{1} H$ NMR spectra of 10 are similar to those of 9 ; only the ${ }^{31} \mathrm{P}$ chemical shifts for both complexes have a slight difference $(\delta 25.66$ of 9 vs $\delta$ 27.63 of 10). However, we have not determined the exact structure of $\mathbf{1 0}$.

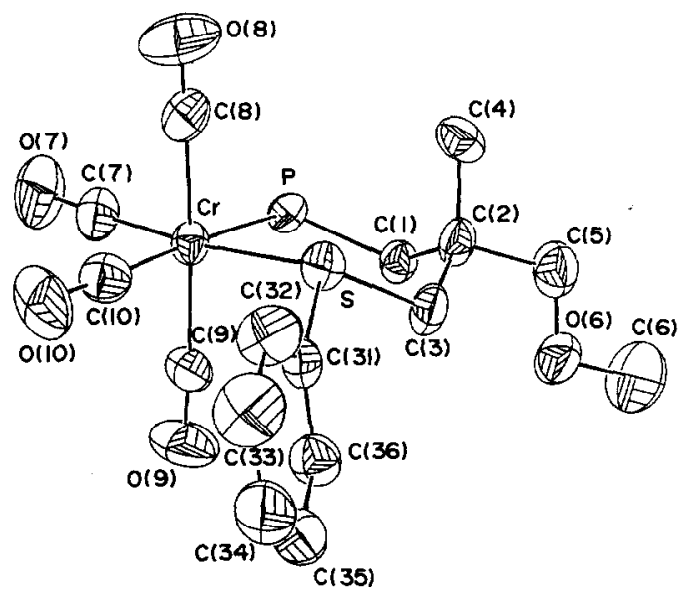

Fig. 2. The ORTEP drawing of $8 \mathrm{a}$ (phenyl groups omitted for clear view).

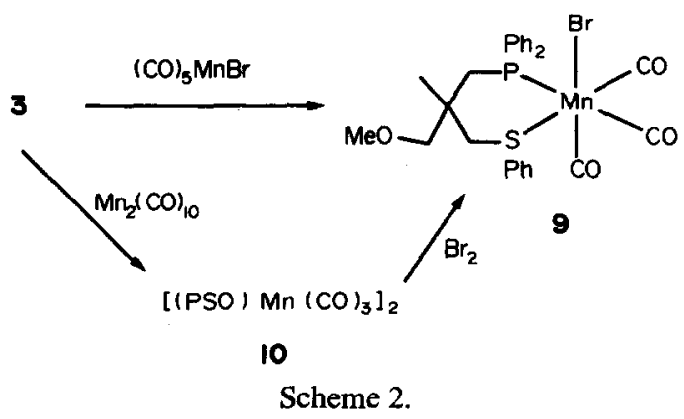

\section{Palladium(II) complex}

The reaction of equimolar amounts of 3 and $\mathrm{PdCl}_{2}$ in acetonitrile afforded the desired complex (PSO) $\mathrm{PdCl}_{2}(11)$ as a yellow, crystalline solid upon recrystallization. Both ${ }^{1} \mathrm{H}$ and ${ }^{31} \mathrm{P}$ NMR spectroscopic data of the compound indicate that the potentially terdentate PSO ligand acts in a bidentate mode with phosphorus and sulphur atoms binding to palladium metal in a cis-fashion. This structure has been further determined by the single-crystal Xray diffraction method. Figure 3 shows an ORTEP view of the complex with all non-hydrogen atoms labelled. The coordination geometry around palladium is a square-planar arrangement with the palladium atom slightly $[0.197(4) \AA]$ out of the plane defined by $\mathrm{S}, \mathrm{P}, \mathrm{Cl}(1), \mathrm{Cl}(2)$. Selected bond dis-

Table 2. Selected bond distances $(\AA)$ and bond angles $\left({ }^{\circ}\right)$ of complexes $8 \mathrm{a}, 8 \mathrm{c}$ and 11

\begin{tabular}{lccc}
\hline & $\mathbf{8 a}$ & $\mathbf{8 c}$ & $\mathbf{1 1}$ \\
& $\mathrm{M}=\mathrm{Cr}$ & $\mathrm{M}=\mathrm{W}$ & $\mathbf{M}=\mathbf{P d}$ \\
\hline $\mathrm{M}-\mathrm{P}$ & $2.385(2)$ & $2.510(3)$ & $2.235(2)$ \\
$\mathrm{M}-\mathrm{S}$ & $2.420(2)$ & $2.546(4)$ & $2.285(2)$ \\
$\mathrm{M}-\mathrm{C}(7)$ & $1.806(6)$ & $1.88(1)$ & \\
$\mathrm{M}-\mathrm{C}(8)$ & $1.911(7)$ & $2.07(1)$ & \\
$\mathrm{M}-\mathrm{C}(9)$ & $1.879(6)$ & $1.82(2)$ & \\
$\mathrm{M}-\mathrm{C}(10)$ & $1.820(6)$ & $1.94(1)$ & \\
$\mathrm{M}-\mathrm{C}(11)$ & & & $2.289(2)$ \\
$\mathrm{M}-\mathrm{C}(12)$ & & & $2.381(2)$ \\
$\mathrm{P}-\mathrm{C}(1)$ & $1.820(5)$ & $1.82(1)$ & $1.830(6)$ \\
S-C(3) & $1.822(6)$ & $1.81(1)$ & $1.824(7)$ \\
$\mathrm{C}(1)-\mathrm{C}(2)$ & $1.549(9)$ & $1.54(2)$ & $1.524(7)$ \\
$\mathrm{C}(2)-\mathrm{C}(3)$ & $1.538(8)$ & $1.56(2)$ & $1.518(9)$ \\
S-M-P & $91.85(7)$ & $89.7(1)$ & $97.81(6)$ \\
$\mathrm{P}-\mathrm{M}-\mathrm{C}(7)$ & $88.8(2)$ & $89.8(4)$ & \\
S-M-C(10) & $92.0(2)$ & $91.2(4)$ & \\
C(7)-M-C(10) & $87.8(3)$ & $89.8(6)$ & \\
C(8)-M-C(9) & $174.7(3)$ & $175.6(5)$ & \\
P-M-C(1) & & & $86.26(7)$ \\
S-M-C(2) & & & $84.77(7)$ \\
C(11)-M-C(12) & & & $91.15(7)$ \\
\hline
\end{tabular}




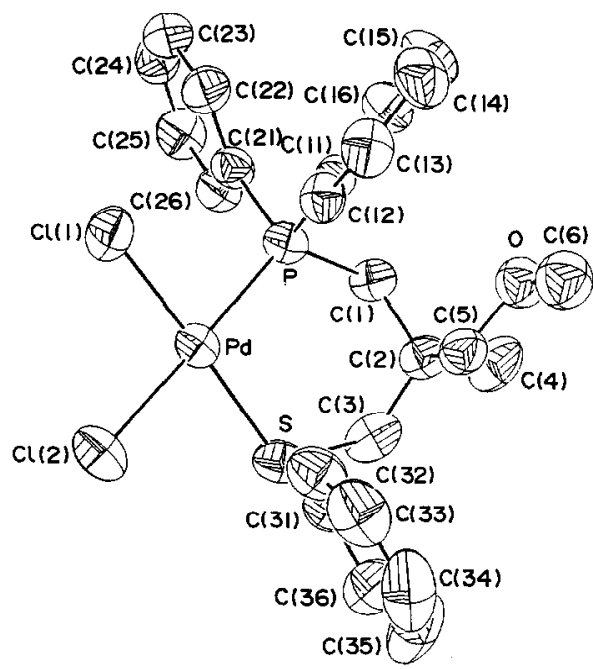

Fig. 3. ORTEP drawing of complex 11.

tances and angles are listed in Table 2. The $\mathrm{Pd}-\mathrm{Cl}$ bond trans to the phosphorus atom is longer, as expected, than that trans to the sulphur atom, probably due to the "trans effect".

\section{Conformational analysis}

Table 3 presents all torsional angles around the six-membered chelate rings of the complexes, which also facilitates their comparison. The characteristic $+g,-g$ alternations indicate the conformations of the six-membered chelate rings of $8 \mathrm{a}, 8 \mathrm{c}$ and 11 to be in chair forms, which are considered the most stable.$^{67}$ However, these chair conformations are all slightly distorted, especially in the palladium complex (Fig. 3).

In the previous investigation, ${ }^{1 \mathrm{a}, 1 \mathrm{~b}}$ we found that the conformations of $\left(\mathrm{P}_{2} \mathrm{~S}\right) \mathrm{Mo}(\mathrm{CO})_{4}$ and $\left(\mathrm{P}_{2} \mathrm{O}\right) \mathrm{Cr}$ $(\mathrm{CO})_{4}$ were in twist-boat forms mainly due to the steric interactions of substituents along the chel-

(a)

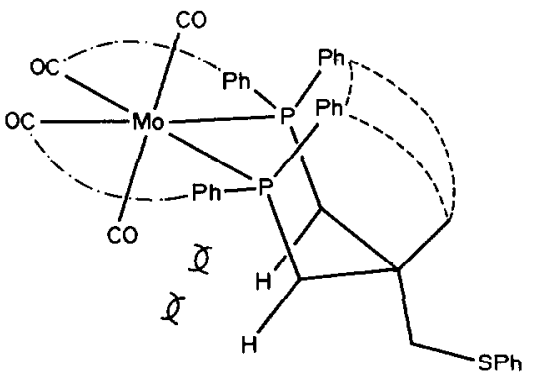

Table 3. Torsional angles $\left({ }^{\circ}\right)$ around the six-membered chelate rings of complexes $8 \mathbf{a}, 8 \mathbf{c}$ and 11

\begin{tabular}{lrcr}
\hline & $\mathbf{8 a}$ & $\mathbf{8 c}$ & \multicolumn{1}{c}{$\mathbf{1 1}$} \\
& $\mathrm{M}=\mathrm{Cr}$ & $\mathrm{M}=\mathrm{W}$ & $\mathrm{M}=\mathrm{Pd}$ \\
\hline $\mathrm{M}-\mathrm{P}-\mathrm{C}(1)-\mathrm{C}(2)$ & $-52.5(3)$ & $-54.1(7)$ & $43.5(3)$ \\
$\mathrm{P}-\mathrm{C}(1)-\mathrm{C}(2)-\mathrm{C}(3)$ & $80.3(4)$ & $81.8(10)$ & $-71.9(4)$ \\
$\mathrm{C}(1)-\mathrm{C}(2)-\mathrm{C}(3)-\mathrm{S}$ & $-81.1(4)$ & $-82.4(10)$ & $67.0(4)$ \\
$\mathrm{C}(2)-\mathrm{C}(3)-\mathrm{S}-\mathrm{M}$ & $57.7(3)$ & $57.6(6)$ & $-34.9(3)$ \\
$\mathrm{C}(3)-\mathrm{S}-\mathrm{M}-\mathrm{P}$ & $-28.8(2)$ & $-28.9(4)$ & $6.4(2)$ \\
$\mathrm{S}-\mathrm{M}-\mathrm{P}-\mathrm{C}(1)$ & $25.4(2)$ & $26.0(4)$ & $-9.9(2)$ \\
\end{tabular}

ate rings, as shown in Fig. 4(a). Apparently, the trivalent thioether (coordination to the metal) helps to relieve some 1,3-diaxial interactions in the chelate rings of complexes $8 \mathbf{a}$ and $8 \mathbf{c}$, so that the chelate rings are able to adopt chair forms [Fig. 4(b)].

In contrast to an equatorial position, the phenyl group attached to the sulphur atom is situated in an axial position in the palladium complex 11. This difference obviously suggests the "eclipsed" interaction of the equatorial phenyl group and the chloride ligand to be larger than the 1,3-diaxial interaction. Of course, another factor contributing to this outcome is that the larger angle of S-Pd-P $\left[97.81(6)^{\circ}\right]$ increases the distance between phosphorus and sulphur, which leads to the decrease of the 1,3-diaxial interaction between the phenyl groups.

The resolution of the chiral ligand PSO and its applications are currently in progress.

\section{EXPERIMENTAL}

The general information has been described in detail previously. ${ }^{1}$ Compound 4 was prepared according to the reported method. ${ }^{8}$

(b)

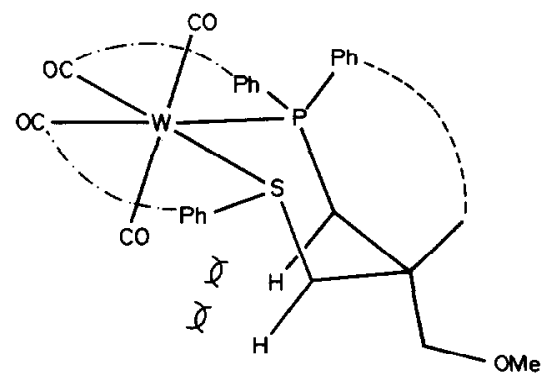

Fig. 4. (a) Three types of major steric interactions of $\left(\mathrm{P}_{2} \mathrm{~S}\right) \mathrm{Mo}(\mathrm{CO})_{4}$ in the chair conformation : (i) 1,3-diaxial interactions (---); (ii) "eclipsed" interactions between apical ligands (CO) and phenyl groups $(-\cdot-\cdot)$; (iii) interactions between apical ligands and axial hydrogen atoms $(\chi)$.

(b) The steric interaction of (PSO) W(CO) ${ }_{4}$ in the chair form. 


\section{3-Methoxymethyl-3-methyloxetane (5)}

Freshly-cut sodium metal $(3.7 \mathrm{~g})$ was added to a solution of $4(16.27 \mathrm{~g}, 0.16 \mathrm{~mol})$ in toluene (40 $\mathrm{cm}^{3}$ ). The mixture was heated to reflux overnight. Iodomethane $\left(12 \mathrm{~cm}^{3}, 0.16 \mathrm{~mol}\right)$ was added to the above solution, which was then stirred at room temperature for $36 \mathrm{~h}$. The reaction mixture was quenched with water $\left(50 \mathrm{~cm}^{3}\right)$ and the organic layer was separated. The organic portion was extracted with ether $\left(20 \mathrm{~cm}^{3} \times 3\right)$. All organic extracts were combined, dried and concentrated. The residue was distilled to give compound $5(10.0 \mathrm{~g}, 54 \%)$ as a clear liquid: b.p. $138-142^{\circ} \mathrm{C} / 760 \mathrm{~mm}$ (similar to literature ${ }^{9}$ ).

\section{2-Hydroxymethyl-2-phenylthiomethyl-1-methoxy- propane (6)}

Freshly-cut sodium metal $(4.15 \mathrm{~g}, 180.4 \mathrm{mmol})$ was added to ethanol $\left(70 \mathrm{~cm}^{3}\right)$ under a nitrogen atmosphere. After all the sodium had reacted, thiophenol $\left(18 \mathrm{~cm}^{3}, 175.3 \mathrm{mmol}\right)$ was added to the ethoxide solution slowly, this was then stirred for $30 \mathrm{~min}$. Compound 5 (6.63 g, $57.2 \mathrm{mmol})$ was transferred into the above solution and the resulting mixture was heated to reflux overnight. Water (20 $\left.\mathrm{cm}^{3}\right)$ followed by ether $\left(40 \mathrm{~cm}^{3}\right)$ was added to the reaction mixture. The organic layer was separated, and the aqueous layer was extracted with ether $\left(30 \mathrm{~cm}^{3} \times 2\right)$. The combined organic extracts were dried and concentrated. The residue was chromatographed on silica $(100 \mathrm{~g})$ with elution by $5 \%$ ethyl acetate in hexane. The desired compound 6 was obtained as a viscous, yellow liquid $(8.08 \mathrm{~g}$, $62 \%) .{ }^{1} \mathrm{H}$ NMR : $\delta 7.40-7.00(\mathrm{~m}, 5 \mathrm{H}), 3.48(\mathrm{~d}$, $J=9 \mathrm{~Hz}, 1 \mathrm{H}), 3.42(\mathrm{~d}, J=9 \mathrm{~Hz}, 1 \mathrm{H}), 3.20(\mathrm{~d}$, $J=3 \mathrm{~Hz}, 2 \mathrm{H}), 3.15(\mathrm{~s}, 3 \mathrm{H}), 3.08(\mathrm{~d}, J=9 \mathrm{~Hz}, 1$ $\mathrm{H}), 2.92(\mathrm{~d}, J=9 \mathrm{~Hz}, 1 \mathrm{H}), 2.70(\mathrm{br}, 1 \mathrm{H}), 0.80(\mathrm{~s}$, $3 \mathrm{H})$. Found : $\mathrm{C}, 63.1 ; \mathrm{H}, 8.1$. Calc. for $\mathrm{C}_{12} \mathrm{H}_{18} \mathrm{O}_{2} \mathrm{~S}$ : $\mathrm{C}, 63.7 ; \mathrm{H}, 8.1 \%$.

\section{2-Diphenylphosphinomethyl-2-phenylthio-1-meth- oxypropane (3)}

The hydroxy compound 6 was transformed into mesylate 7 according to a standard procedure described previously. ${ }^{1 \mathrm{~b}}$ To a solution of diphenylphosphine $(3.23 \mathrm{~g}, 17.2 \mathrm{mmol})$ in THF $\left(100 \mathrm{~cm}^{3}\right)$ was added a $2.50 \mathrm{M}$ hexane solution of $n$-butyllithium $\left(17.0 \mathrm{~cm}^{3}\right)$ at ice-cooled temperature. After stirring for $30 \mathrm{~min}$, compound $7(4.24 \mathrm{~g}, 13.9 \mathrm{mmol})$, in a small portion of THF, was added to the phosphide anion solution. The resulting mixture was heated to reflux for $4 \mathrm{~h}$; degassed water $\left(10 \mathrm{~cm}^{3}\right)$ was then added. The organic layer was separated, dried and concentrated. The crude product was chromatographed on silica $(100 \mathrm{~g})$ with elution by $40 \%$ ethyl acetate in hexane. The desired tripodal ligand, PSO, was obtained as a viscous, colourless

Table 4. Summary of crystal data of complexes $8 \mathbf{8}, \mathbf{8 c}$ and 11

\begin{tabular}{|c|c|c|c|}
\hline & $\mathbf{8 a}$ & $8 \mathbf{c}$ & 11 \\
\hline Formula & $\mathrm{CrPSC}_{28} \mathrm{H}_{27} \mathrm{O}_{5}$ & $\mathrm{WPSC}_{28} \mathrm{H}_{27} \mathrm{O}_{5}$ & $\mathrm{PdPSC}_{24} \mathrm{H}_{23} \mathrm{Cl}_{2} \mathrm{O}$ \\
\hline Crystal size (mm) & $0.7 \times 0.7 \times 0.5$ & $0.6 \times 0.6 \times 0.5$ & $0.5 \times 0.5 \times 0.5$ \\
\hline Lattice & Orthorhombic & Orthorhombic & Orthorhombic \\
\hline Space group & Pna2, & $\operatorname{Pna2}_{1}$ & Pbca \\
\hline$a(\AA)$ & $16.786(8)$ & $16.896(8)$ & $16.223(3)$ \\
\hline$b(\AA)$ & $12.728(9)$ & $12.768(4)$ & $15.447(3)$ \\
\hline$c(\AA)$ & $12.754(4)$ & $12.837(5)$ & $19.737(3)$ \\
\hline$V\left(\AA^{3}\right)$ & 2725.1 & 2769.3 & 4945.7 \\
\hline$Z$ & 4 & 4 & 8 \\
\hline$F(000)$ & 1088 & 1240 & 2064 \\
\hline Temperature (K) & 300 & 300 & 300 \\
\hline$\mu\left(\mathrm{mm}^{-1}\right)$ & 0.57 & 4.42 & 1.11 \\
\hline Transmission & $0.94-1.0$ & $0.65-1.0$ & $0.85-1.0$ \\
\hline $2 \theta_{\max }$ & 54 & 55 & 50 \\
\hline$h, k, l$ & $21,16,16$ & $21,16,16$ & $19,18,23$ \\
\hline$\lambda(\AA)$ & 0.7093 & 0.7093 & 0.7093 \\
\hline Number of reflections & 3097 & 3318 & 4350 \\
\hline Number of observed reflections & $2208(>2.5 \sigma)$ & $2477(>2.0 \sigma)$ & $2682(>2.5 \sigma)$ \\
\hline Number of variables & 325 & 325 & 270 \\
\hline$R(F)$ & 0.045 & 0.040 & 0.037 \\
\hline$R_{\mathrm{w}}(F)$ & 0.034 & 0.037 & 0.037 \\
\hline$S$ & 2.42 & 3.81 & 2.87 \\
\hline
\end{tabular}


liquid. ${ }^{1} \mathrm{H}$ NMR : $\delta 7.60-7.00(\mathrm{~m}, 15 \mathrm{H}), 3.10(\mathrm{~s}, 2$ $\mathrm{H}), 3.00(\mathrm{~s}, 3 \mathrm{H}), 2.90(\mathrm{~s}, 2 \mathrm{H}), 2.20\left(\mathrm{~d}, J_{\mathrm{P}-\mathrm{C}-\mathrm{H}}=3\right.$ Hz. 2 HI. 0.90 (s. 3 H]. Found: C, 73.T; H. 7.0. Calc. for $\mathrm{C}_{24} \mathrm{H}_{27} \mathrm{OPS}$ : C, $73.1 ; \mathrm{H}, 6.9 \%$.

\section{Preparation of $\mathbf{8 a - 8 c}$}

The ligand PSO and an equimolar amount of group VI metal carbonyl $\left(\mathrm{M}(\mathrm{CO})_{6,}, \mathrm{M}=\mathrm{Cr}\right.$, Mo and W) were dissolved in as aromatic solvest (toluene or xylene) and heated to refsux for 8-10 b. The aesirea compiexes were isolatea b́y chrromatography on suitca. All spectrosconic and anatyutic data are given in Table 1.

\section{Preparation of (PSO) $\mathrm{Mn}(\mathrm{CO})_{3} \mathrm{Br}(9)$}

A solution of $\mathrm{BrMn}(\mathrm{CO})_{5}(45.7 \mathrm{mg}, 0.17 \mathrm{mmol})$ and PSO (65.5 $\mathrm{mg}, 0.17 \mathrm{mmol})$ in chloroform was refluxed for $30 \mathrm{~min}$. After addition of hexane, the solution was allowed to stand for several days. The complex fac-(PSO) $\mathrm{Mn}(\mathrm{CO})_{3} \mathrm{Br}$ was crystallized as yellowish needles $(65.3 \mathrm{mg}, 64 \%)$. IR: $v(C=0)$ 2034, 1961, $1907 \mathrm{~cm}^{-1} .{ }^{1} \mathrm{H}$ NMR: $\delta 7.90-7.30(\mathrm{~m}$, $15 \mathrm{H}), 3.25(\mathrm{~s}, 3 \mathrm{H}), 3.09$ (d, $J=8.84 \mathrm{~Hz}, 1 \mathrm{H}), 3.03$ $(\mathrm{d}, J=8.84 \mathrm{~Hz}, 1 \mathrm{H}), 2.71(\mathrm{~d}, J=11 \mathrm{~Hz}, 1 \mathrm{H}), 2.64$ (d, $J=11 \mathrm{~Hz}, 1 \mathrm{H}$ ), 2.44 (dd, $J=10,15.3 \mathrm{~Hz}, 1$ H), 2.15 (dd, $J=10,15.3 \mathrm{~Hz}, 1 \mathrm{H}$ ), $0.61(\mathrm{~s}, 3 \mathrm{H})$. ${ }^{31} \mathrm{P}$ NMR : $\delta$ 25.66. Found: C, 48.7; H, 4.0. Calc. for $\mathrm{C}_{27} \mathrm{H}_{27} \mathrm{O}_{4} \mathrm{PSMnBr}$ : C, $49.1 ; \mathrm{H}, 4.1 \%$.

\section{Preparation of (PSO) $\mathrm{PdCl}_{2}$ (11)}

This complex was obtained as a yellow, crystalline solid by stirring a mixture of PSO and $\mathbf{P d C l}_{2}$ in acetonitrile, followed by recrystallization from dichloromethane and ethyl acetate, m.p. (dec.) $190^{\circ} \mathrm{C} .{ }^{1} \mathrm{H}$ NMR : $\delta$ 7.94-7.30 (m, $\left.15 \mathrm{H}\right), 3.03(\mathrm{~s}, 3$ H), $2.97(\mathrm{~d}, J=5 \mathrm{~Hz}, 1 \mathrm{H}), 2.95(\mathrm{~d}, J=5 \mathrm{~Hz}, 1 \mathrm{H})$, $2.89(\mathrm{~d}, J=2.7 \mathrm{~Hz}, 1 \mathrm{H}), 2.87(\mathrm{~d}, J=2.7 \mathrm{~Hz}, 1 \mathrm{H})$, 2.49 (dd, $J=22.5,12 \mathrm{~Hz}, 1 \mathrm{H}$ ), 2.09 (dd, $J=22.5$, $12 \mathrm{~Hz}, 1 \mathrm{H}), 0.93(\mathrm{~s}, 3 \mathrm{H}) .{ }^{31} \mathrm{P}$ NMR : $\delta 17.81$.
Found: $\mathrm{C}, 50.1 ; \mathrm{H}$, 4.7. Calc. for $\mathrm{C}_{24} \mathrm{H}_{27} \mathrm{OP}$ $\mathrm{SPdCl}_{2}: \mathrm{C}, 50.4 ; \mathrm{H}, 4.8 \%$.

Crystallographic analysis of complexes $\mathbf{8 a}, 8 \mathbf{c}$ and 11

Cell parameters were determined on a CAD-4 diffractometer by a least-squares treatment. Atomic scattering factors wee taken from the International Tables for $Y$-ray Erystallography: ${ }^{10}$ Computation was carried out by using the NRCC SDP VAX package. "Reíevant data are summarizer in. Tahie 4.

Acknowledgement-Financial support from the National Science Council (R.O.C.) is acknowledged.

\section{REFERENCES}

1. (a) S.-T. Liu, II.-E. Wang, M.-C. Cheng and S.-M. Peng, J. Organomet. Chem. 1989, 376, 333; (b) S.-T. Liu, G.-J. Liu, C.-H. Yieh, M.-C. Cheng and S.-M. Peng, J. Organomet. Chem. 1990, 387, 83 ; (c) S.-T. Liu, C.-H. Yieh and H.-J. Lu, Phosphorus, Sulfur and Silicon 1989, 44, 261.

2. S. G. Murray and F. R. Hartley, Chem. Rev. 1981, 81,365 and refs therein.

3. For recent review in tripodal polyphosphines see: $\mathbf{L}$. Sacconi and F. Mani, in Transition Metal Chemistry (Edited by G. A. Melson and B. N. Figgis), Vol. 8, p. 179. Marcel Dekker, New York (1982).

4. M. F. Lappert, D. B. Shaw and G. M. McLaughlin, J. Chem. Soc., Dalton Trans. 1979, 427.

5. C. S. Kraihanzel, J. M. Ressner and G. M. Gray, Inorg. Chem. 1982, 21, 879.

6. J. R. Gollogly and C. J. Hawkins, Inorg. Chem. 1972, 11, 156.

7. M. R. Churchill, A. L. Rheingold and R. L. Keiter, Inorg. Chem. 1981, 20, 2730.

8. D. B. Pattison, J. Am. Chem. Soc. 1957, 79, 3455.

9. A. J. McAlees, R. McCrindle and A. R. Woon-Fat, Inorg. Chem. 1976, 15, 1065.

10. International Tables for X-ray Crystallography, Vol. IV. Kynoch Press, Birmingham (1974).

11. E. J. Gabe and F. L. Lee, Acta Cryst. 1981, A37, S339. 